\title{
Verzeichniss \\ der Herren, welche für den achten Band Referate geliefert haben.
}

(Die Verantwortlichkeit für den Inhalt der Referate tragen die Herren Referenten. Die in Klammern gesetzten Chiffern bezeichnen die Uebersetzer der in fremder Sprache eingesandten Beferate).

Herr Prof. August in Berlin.

A. Herr Prof. Mansion in Gent. Mo.

- Dr. Aron in Charlotteoburg.

Prof Baraniecti inWarschau. Bcti.

- Prof. Mayer in Leipzig. Mr.

- Prof. Björling in Lund.

- Prof. Brill in München.

- Dr. Maynz in Ludwigslust.

Mz.

- Prof. Bruns in Berlin.

Bg. - Prof. Mitlag-Leffler in Helsingfors.

M-L.

- Dr. Benno Klein in Berlio. B.K.

- Dr. F. Müller in Berlin. M.

- Prof. Casey in Dublin.

B. K.

- Prof. Cayley in Cambridge.

- Dickstein in Warschau.

Dr. Netto in Herlio.

M.

- Prof. Neumana in Leipzig. No.

- Prof. van Geer in Leiden.

Dn.

- Prof. Nöther in Erlangen.

Nr.

- Prof. Gla isher in Cambridge. Glr.

- Gram in Kopenhagen.

Gm.

Prof. Gü ntber in Ansbach. Gr.

- Dr, Ohrtmann in Berlin.

- Dr. Oberbeck in Hallea.S. Ok.

- Dr. von Posse in Petersburg. P.

- Dr. Schemmel in Berlin. Schl.

- Dr. Schlegel in Waren. Schg.

Prof. Gyldén in Stockbolm. Gn. - Dr. Scholz in Berlin. Scbz.

- Dr. Hamburger in Berlin. Hr. - Dr. Schubert in Hamburg. Scht.

- Prof. Hoppe in Berlin.

Prof. Jung in Mailand.

H.

- Dr. Schubert in Hamburg. Scht.

Prof. Felix Klein in München. Kln.

- Prof. Lie to Christiania.

- Prof. Lindelöf in Upsala.

- Prof. Lüroth in Carlsruhe.

- Prof. Stolz in Innsbruck. St.

- Prof. Sturm in Mũnster. Sm.

- Prof. Wangerin in Berlin. Wa.

- Prof. Ed. Weyr in Prag. W.

Briefe und Zusendungen erbitten wir entweder durch Vermittelung der Verlagshandlung oder unter der Adresse:

Dr. C. Ohrtman n, Berlin SW., Markgrafenstr. 78. III. 